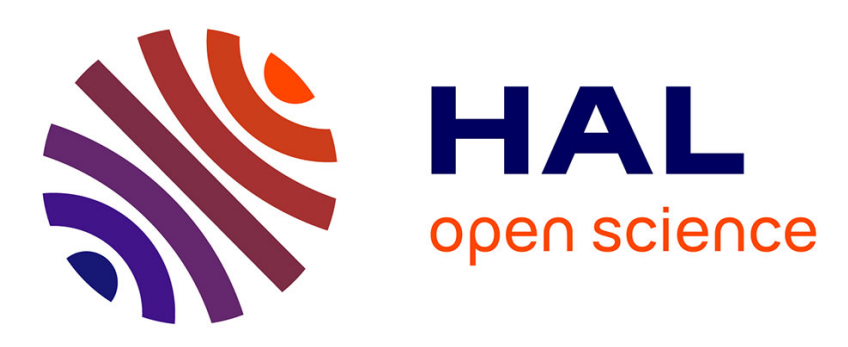

\title{
Nature-inspired algorithms for optimal active band pass Filter design
}

\author{
Asmae El Beqal, Loubna Kritele, Bachir Benhala, Izzedine Zorkani
}

\section{To cite this version:}

Asmae El Beqal, Loubna Kritele, Bachir Benhala, Izzedine Zorkani. Nature-inspired algorithms for optimal active band pass Filter design. International Meeting on Advanced Technologies in Energy and Electrical Engineering (IMAT3E18), Nov 2018, Fès, Morocco. hal-01959009

\section{HAL Id: hal-01959009 \\ https://hal.science/hal-01959009}

Submitted on 18 Dec 2018

HAL is a multi-disciplinary open access archive for the deposit and dissemination of scientific research documents, whether they are published or not. The documents may come from teaching and research institutions in France or abroad, or from public or private research centers.
L'archive ouverte pluridisciplinaire HAL, est destinée au dépôt et à la diffusion de documents scientifiques de niveau recherche, publiés ou non, émanant des établissements d'enseignement et de recherche français ou étrangers, des laboratoires publics ou privés. 
 \\ Engineering
}

\section{Nature-inspired algorithms for optimal active band pass Filter design}

\author{
${ }^{1} *$ EL BEQAL Asmae, ${ }^{1}$ KRITELE Loubna, ${ }^{2}$ BENHALA Bachir \& ${ }^{1}$ ZORKANI Izeddine \\ ${ }^{1}$ asmae.elbekkal@gmail.com,Faculty of Sciences Dhar el Mahraz, Morroco \\ ${ }^{2}$ Faculty of Sciences, University of Moulay Ismail, Morroco
}

The basic purpose in active filters design is to calculate the filter transfer function in order to find the adequate discrete components values (Resistors and Capacitors) forming those filters, which providing the best performances. The selection of the components values must be from industrial series so as to reduce costs and make the design more feasible, then, the search for an optimal set of component values from the numerous possible combinations appears to be an exhaustive process, thus diverting the attention towards the application of the metaheuristics which combines high efficiency with minimal computational time.

In the literature, various metaheuristics were used for optimal design of analog circuits such as Simulated Annealing (SA) [1], Tabu Search (TS) [2], Particle Swarm Optimization (PSO) [3], Ant Colony Optimization (ACO) [4] and Genetic Algorithms (GA) [5].

In this paper, we propose to apply the Ant Colony Optimization (ACO) [4] and the Genetic Algorithm (GA) [5] techniques, which are increasingly used in the domains of optimization and has been applied successfully in the field of analog circuits, for the optimal sizing of the second order active band pass filter namely Sallen Key (Figure 1), considering two objectives functions, the mid frequency and the selectivity factor.

ACO is a metaheuristic developed in order to solve difficult optimization problems. It has been inspired by the foraging behavior of real ant colonies. Its basic idea is the indirect communication between the ants mediated by trails of chemical substance, called pheromone, which allows them to find the shortest path from their nest to the food source, while GA is a search heuristic that is inspired by Charles Darwin's theory of natural evolution. This algorithm reflects the process of natural selection where the fittest individuals are selected for reproduction in order to produce offspring of the next generation.

The objective function considered is the Total Error $\left(\mathrm{TE}_{\mathrm{SK}}\right)$ given in (1), which expresses the offset values, of the mid frequency and the selectivity factor, compared to the desired values $\left(\omega_{m}=6.28 \mathrm{k} \mathrm{rad} / \mathrm{s}\left(f_{m}=1 \mathrm{KHz}\right)\right.$ et $\left.Q=10\right)$. The decision variables are the resistors and capacitors forming the circuit. Each component must have a value of the 


\section{Engineering}

standard series (E12, E24, E48, E96, and E192). The validity of the proposed techniques was proved via PSPICE simulations (Figure 2).

$T E_{S K}=0.5 \Delta \omega_{S K}+0.5 \Delta Q_{S K}$

where :

$\Delta \omega_{S K}=\frac{\left|\frac{1}{R C}-\omega_{m}\right|}{\omega_{m}} \quad \Delta Q_{S K}=\frac{\left|\frac{R_{1}}{2 R_{1}-R_{2}}-Q\right|}{Q}$

The table I presents the optimal values of resistors and capacitors forming the studied filter and the performance associated with these values following the series that gave us the best result for both algorithms, according to the result ACO algorithm achieves the smallest values of the design error.

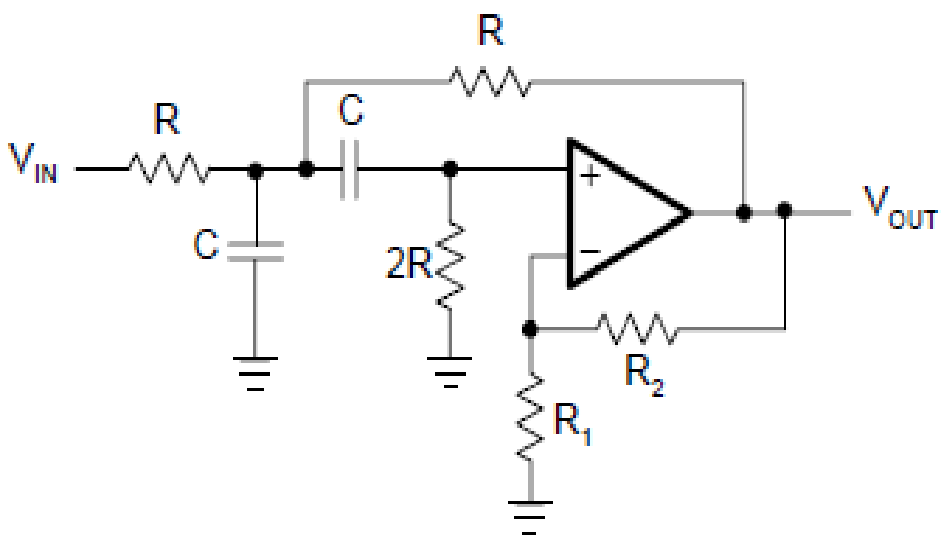

Figure 1. Schematic diagram of 2nd order Sallen-Key active band-pass filter

Table I. Values of component and related filter performance for the ACO and GA

\begin{tabular}{|lcccc|ccc|}
\cline { 2 - 8 } \multicolumn{1}{c|}{} & $\mathrm{R} 1$ & $\mathrm{R} 2$ & $\mathrm{R}$ & $\mathrm{C}$ & $\boldsymbol{\Delta \omega}_{\text {SK }}$ & $\Delta \mathbf{Q}_{\text {SK }}$ & TE $_{\text {SK }}$ \\
\hline ACO (E192) & 25.20 & 48.01 & 45.30 & 3.48 & 0.0101 & 0.0544 & 0.0322 \\
\hline AG (E96) & 24.90 & 47.50 & 02.61 & 60.40 & 0.0101 & 0.0826 & 0.0464 \\
\hline
\end{tabular}


IMAT3E' 18

International Meeting on Advanced Technologies in Energy and Electrical

Engineering

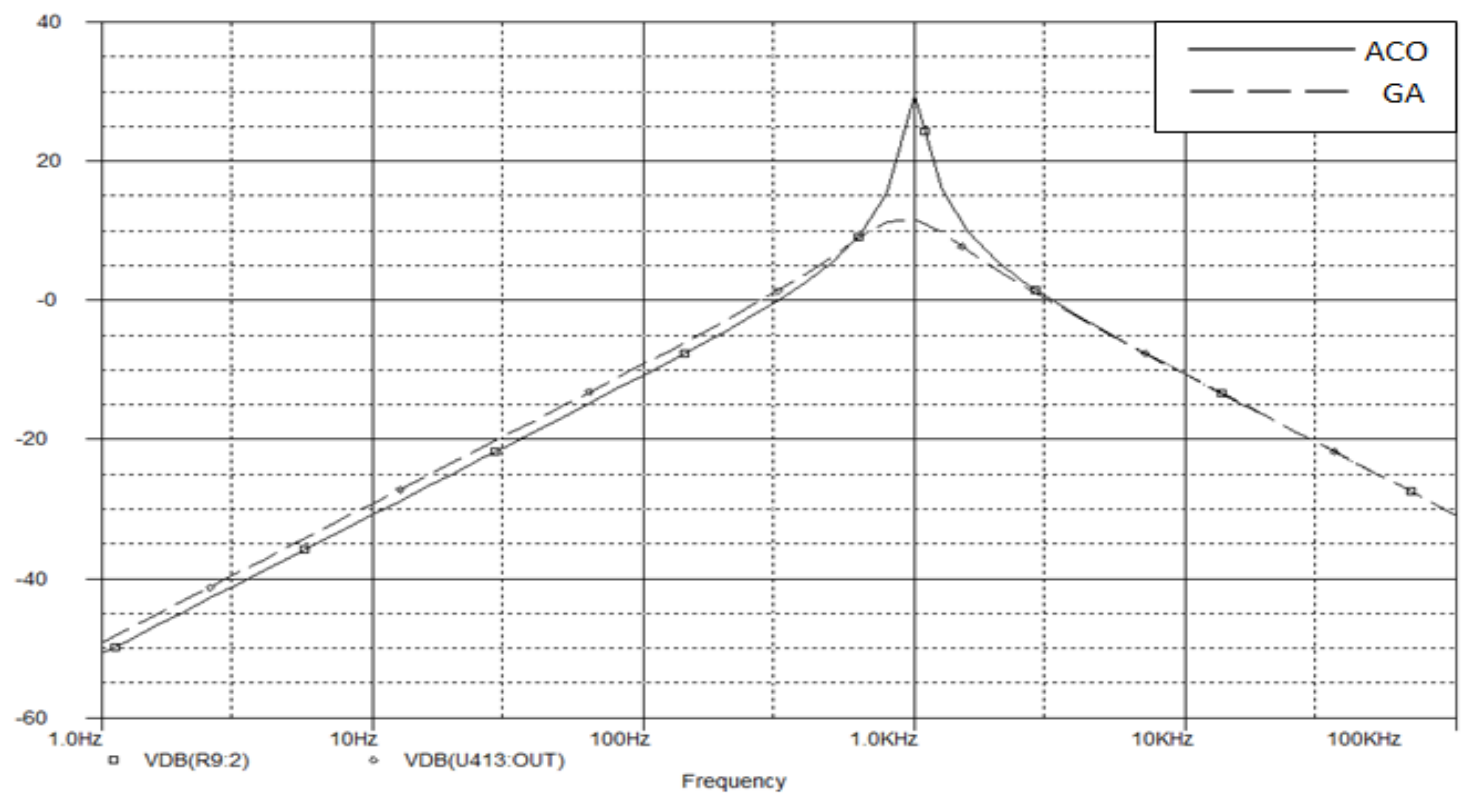

Figure 2. Frequency responses of second order Sallen-Key active band-pass Filter

In this work, we have successfully selected the values of discrete components from different manufactured series for the optimal sizing of the second order Sallen-Key active band-pass filter, the topology of Sallen Key can be used to design the 4th order Butterworth active band-pass filter which is used for radio frequency identification (RFID) system reader to reject all signals outside the band $(10-20) \mathrm{kHz}$ and to amplify the low antenna signal, that can be detailed in a future work.

\section{References}

1. J. Dreo, A. Pe'trowski, P. Siarry, E. Taillard, "Metaheuristics for hard optimization: Methods and case studies", New York: Springer, 2006.

2. F. Glover, "Tabu search-part I', ORSA Journal on computing, 1(3), 190-206, 1989.

3. F. T. S. Chan, M. K. Tiwari, "Swarm Intelligence: focus on ant and particle swarm optimization’, I-Tech Education and Publishing, 2007.

4. L. Kritele, B. Benhala, and I. Zorkani, "Ant Colony Optimization for Optimal Analog Filter Sizing", Chapter 10, Book: Focus on swarm intelligence research and applications, Eds., B. Benhala, P. Pereira and A. Sallem, NOVA Science Publishers, pp. 193-220, 2017.

5. J. B. Grimbleby, "Automatic analogue circuit synthesis using genetic algorithms", IEE Proceedings-Circuits, Devices and Systems, 147(6), 319-323, 2000. 